\title{
Webinar: Upaya Mendukung Keberhasilan Pemberian ASI Eksklusif
}

\author{
1*Dyah Intan Puspitasari, ${ }^{1}$ Siti Nurokhmah, ${ }^{1}$ Setyaningrum Rahmawaty \\ ${ }^{1}$ Program Studi Ilmu Gizi, Fakultas Ilmu Kesehatan, Universitas Muhammadiyah Surakarta \\ *Penulis korespondensi, email: dip297@ums.ac.id
}

(Received: 15 July 2021/Accepted: 17 January 2022/Published: 31 January 2022)

\begin{abstract}
Abstrak
Memberikan ASI eksklusif memiliki manfaat yang sangat besar bagi ibu dan juga bayi. Untuk mencapai target nasional (80\%) cakupan ASI eksklusif, diperlukan berbagai upaya, salah satunya adalah dengan memberikan edukasi kesehatan. Pemberian edukasi bertujuan untuk meningkatkan pengetahuan dan pemahaman agar nantinya kelompok sasaran ini dapat berperan aktif dalam mendukung keberhasilan ASI eksklusif. Kegiatan pengabdian dilakukan dengan memberikan edukasi melalui Webinar kepada masyarakat. Materi yang diberikan adalah kebijakan terkait ASI eksklusif, manfaat ASI, dan juga kiat menyusui pada ibu bekerja. Secara umum kegiatan berlangsung dengan lancar. Peserta memiliki antusias yang tinggi dalam mengikuti kegiatan tersebut dengan memberikan berbagai pertanyaan pada sesi diskusi. Pengetahuan peserta juga mengalami peningkatan secara signifikan $(p=0,000)$ terlihat dari peningkatan nilai pretest dan posttest dari rata-rata 7,29 menjadi 8,55. Kegiatan Webinar series dengan tema yang mendukung praktek-praktek menyusui yang direkomendasikan dan terbentuknya komunitas yang mendukung ASI eksklusif diharapkan menjadi upaya tindak lanjut untuk mendukung keberhasilan ASI eksklusif.
\end{abstract}

Kata Kunci: ASI eksklusif, edukasi, pengetahuan, webinar

\begin{abstract}
Exclusive breastfeeding has enormous benefits for both mothers and babies. Health education is one of the programs that may support the achievement of the national target (80\%) of exclusive breastfeeding. Education on exclusive breastfeeding aims to improve knowledge and understanding of targeted group in order to support the success of exclusive breastfeeding. The materials of Webinar including policies related to exclusive breastfeeding, the benefits of breastfeeding, and also breastfeeding tips for working mothers. Participants had high enthusiasm in participating on Webinar activities by asking various questions in the discussion session. The score of knowledge of the participants also increased significantly $(p=0,000)$ from an average 7.29 (pre test) to 8.55 (post test). Webinars series with themes that support recommended breastfeeding practices and develop a community service that supports exclusive breastfeeding are expected as follow-up programs that contribute to the success of exclusive breastfeeding.
\end{abstract}

Keywords : exclusive breastfeeding, education, knowledge, webinar

\section{Pendahuluan}

Memberikan Air Susu Ibu (ASI) saja tanpa adanya makanan ataupun minuman lain kepada bayi yang baru lahir sampai usia 6 bulan, atau sering disebut dengan istilah ASI eksklusif memiliki manfaat yang sangat besar (WHO, 2021). Manfaat ini dapat dirasakan tidak hanya bagi bayi namun juga bagi ibu. Pemberian ASI eksklusif merupakan langkah yang paling optimal dalam memenuhi kebutuhan gizi anak. Hal ini dikarenakan pada 6 bulan pertama kehidupan, kebutuhan gizi anak dapat tercukupi sepenuhnya dari ASI (Meek et al., 2020). Pemberian ASI eksklusif juga bermanfaat dalam menjaga imunitas bayi dan melindungi dari berbagai penyakit 
infeksi dan kronis. ASI eksklusif juga dapat menurunkan angka kematian bayi yang disebabkan karena berbagai penyakit. Selain bermanfaat bagi bayi, ibu yang menyusui juga memperoleh manfaat dari memberi ASI eksklusif pada anaknya yaitu dapat menurunkan risiko kanker payudara, membantu proses Keluarga Berencana $(\mathrm{KB})$ alami, dan memberikan manfaat secara ekonomi (Rollins et al., 2016; Victora et al., 2016).

Menurut laporan Survey Demografi dan Kesehatan Indonesia (SDKI) 2017, cakupan pemberian ASI eksklusif di Indonesia adalah 51,4\%. Cakupan pemberian ASI eksklusif di provinsi Jawa Tengah, pada tahun 2019 mengalami peningkatan dibandingkan pada tahun 2017 yaitu dari $54,4 \%$ menjadi $66 \%$. Persentase bayi yang mendapatkan ASI eksklusif di Kota Surakarta pada tahun 2019 adalah 79,6\% (Dinas Kesehatan Jawa Tengah., 2019). Cakupan ASI eksklusif ini masih di bawah target nasional (80\%) sehingga berbagai upaya perlu dilakukan untuk meningkatkan persentase ibu yang memberikan ASI eksklusif.

Keberhasilan pemberian ASI eksklusif dipengaruhi oleh banyak faktor, termasuk didalamnya adalah peran dari pemerintah, tenaga kesehatan, dan dari ibu itu sendiri. Pemerintah melalui kebijakannya dapat membantu tercapainya program ASI eksklusif. Tenaga Kesehatan berperan dalam memberikan konseling dan dukungan kepada ibu (Endeshaw et al., 2017), sedangkan para kader posyandu berperan sebagai dukungan dari komunitas dalam membantu keberhasilan program ASI eksklusif (Kavle et al., 2017). Masih kurangnya pemahaman, mispersepsi dan misinformasi yang diterima oleh ibu dapat menjadi penyebab rendahnya cakupan ASI eksklusif. Selain itu, ibu yang bekerja dapat menjadi faktor penghambat dalam keberhasilan ASI eksklusif dimana prevalensi pemberian ASI ekslusif cenderung lebih rendah pada ibu yang bekerja (Kavle et al., 2017). Oleh karena itu, program peningkatan pengetahuan dengan pemberian edukasi kepada pihak-pihak terkait dapat membantu keberhasilan pemberian ASI eksklusif pada bayi hingga usia 6 bulan. Selain itu, calon ibu juga perlu untuk memperoleh informasi yang berkaitan dengan ASI eksklusif. Hal ini dikarenakan ibu baru biasanya masih memiliki sedikit pengalaman dan pemahaman terkait ASI eksklusif sehingga dapat menjadi faktor penghambat keberhasilan ASI eksklusif (Kemenkes, 2018).

Pemberian edukasi merupakan salah satu cara yang dapat dilakukan untuk meningkatkan pengetahuan. Edukasi gizi yang tepat dan adekuat dapat meningkatkan pemahaman dan meningkatkan skor pengetahuan (Aktaç et al., 2018). Terdapat banyak metode edukasi yang dapat dilakukan, salah satunya adalah dengan memberikan edukasi melalui webinar. Webinar menjadi salah satu alternatif yang dapat dilakukan untuk menyampaikan informasi kepada audiens pada masa pandemi ini. Melalui webinar, informasi dapat disampaikan kepada audiens secara luas dengan tetap memberikan kesempatan untuk memberikan umpan balik dan interaksi antara narasumber dan audiens (Toquero \& Talidong, 2020).

Kegiatan webinar ini bertujuan untuk memberikan edukasi kepada masyarakat terkait upaya-upaya mendukung keberhasilan ASI eksklusif. Sebagai bentuk kolaborasi dari berbagai profesi, kegiatan webinar mengundang narasumber dari dinas kesehatan, akademisi, dan juga ibu balita yang bekerja, yang masing-masing memberikan materi terkait kebijakan ASI eksklusif, manfaat ASI eksklusif, dan kiat untuk tetap memberikan ASI selama bekerja agar keberhasilan ASI eksklusif dapat tercapai.

\section{Metode}

Berdasarkan analisis situasi, pelaksanaan pengabdian masyarakat dilakukan melalui kegiatan Webinar kepada masyarakat. Materi Webinar diberikan dengan media powerpoint yang meliputi kebijakan terkait ASI eksklusif, manfaat menyusui dilihat dari segi fisiologis dan kesehatan, serta kiat menyusui bagi ibu bekerja. Materi disampaikan oleh 3 (tiga) orang narasumber yang berasal dari Dinas Kesehatan Kota Surakarta, Dosen Prodi Ilmu Gizi Universitas Muhammadiyah Surakarta, dan juga Ibu menyusui yang Bekerja. Metode Webinar melalui Zoom dipilih dikarenakan kondisi pandemi saat ini yang tidak memungkinkan untuk mengumpulkan 
audiens dalam jumlah banyak secara luring. Pelaksanaan kegiatan dimulai dengan tahap persiapan yaitu penyusunan Terms of Reference (TOR) Webinar, menghubungi narasumber, dan melakukan publikasi kegiatan Webinar kepada kelompok sasaran melalui media WhatsApp. Pada tahap persiapan juga dilakukan penyusunan soal untuk pre test dan post test (Tabel 1). Jumlah soal yang digunakan untuk pretest dan post test ini berjumlah 10 soal yang terdiri dari soal pilihan ganda dan pernyataan benar/salah. Tahap pelaksaaan dilakukan dengan memberikan pre test kepada peserta dan dilanjutkan pemberian materi dari ketiga narasumber (masing-masing narasumber memberikan materi selama kurang lebih 200 menit). Kegiatan dilanjutkan dengan sesi diskusi dan tanya jawab kepada ketiga narasumber yang dipandu oleh moderator. Kegiatan diakhiri dengan memberikan post test kepada peserta. Pre test dan post test diberikan kepada peseta melalui google form. Pada tahap akhir dilakukan analisis hasil pre test dan post test secara kuantitatif dengan uji Wilcoxon menggunakan program SPSS 20, evaluasi saran yang diberikan oleh peserta, penyusunan laporan pengabdian, dan publikasi pengabdian pada jurnal. Alur pelaksanaan kegiatan pengabdian ditampilkan pada Gambar 1.

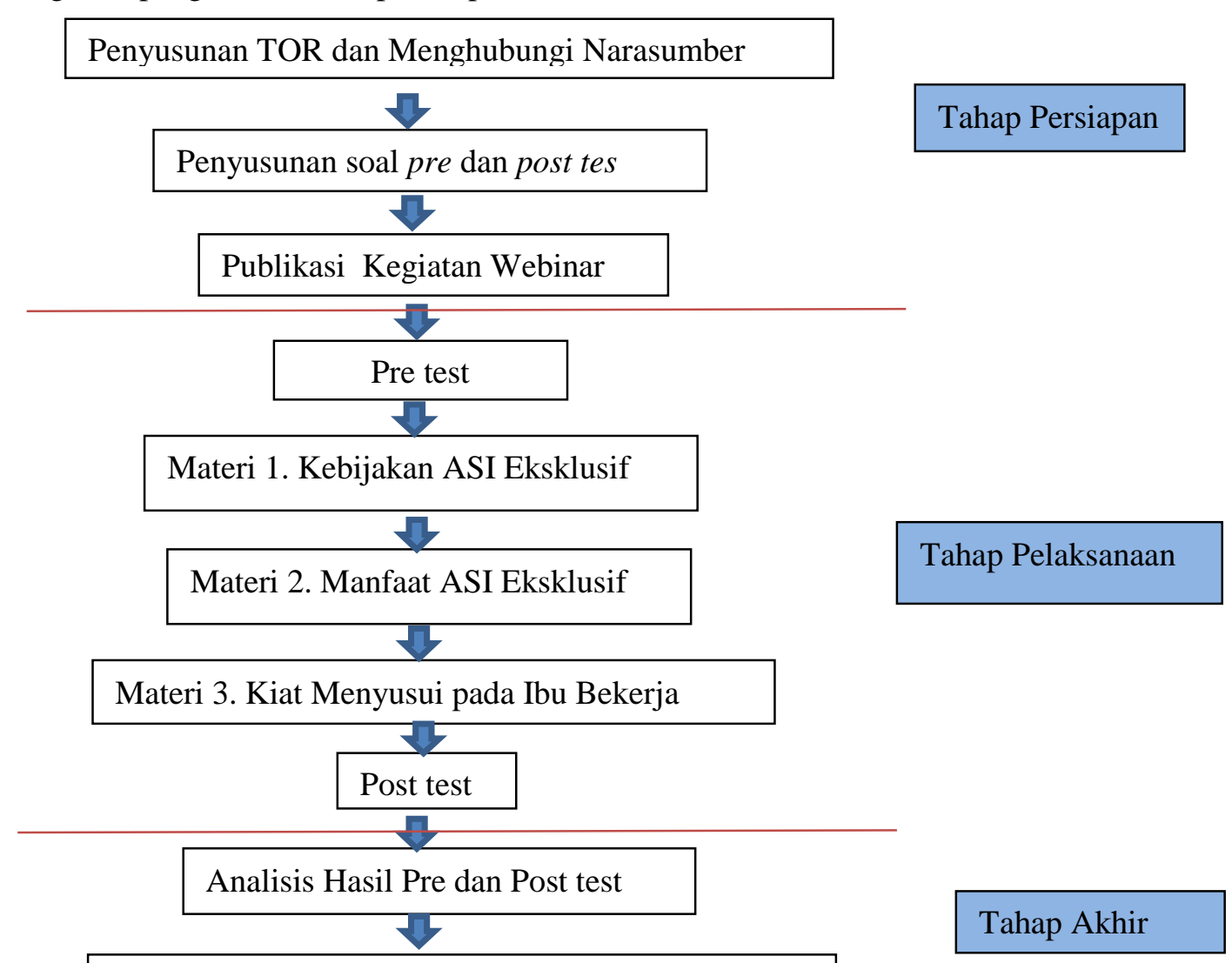

Penyusunan Laporan Pengabdian dan Publikasi

Gambar 1. Alur Pelaksanaan Kegiatan Pengabdian

Tabel 1. Pertanyaan dalam Pre-test dan Post-test

\begin{tabular}{clc}
\hline No. & \multicolumn{1}{c}{ Pertanyaan } & Pilihan Jawaban \\
\hline 1 & $\begin{array}{l}\text { Jarak waktu memompa ASI yang ideal saat di kantor } \\
\text { bagi ibu bekerja }\end{array}$ & Pilihan ganda \\
2 & $\begin{array}{l}\text { Cara penanganan yang dianjurkan pada pompa ASI } \\
\text { setelah digunakan pada 1 sesi pumping di kantor }\end{array}$ & Pilihan ganda
\end{tabular}




\begin{tabular}{clc}
\hline No. & \multicolumn{1}{c}{ Pertanyaan } & Pilihan Jawaban \\
3 & $\begin{array}{l}\text { Daya tahan maksimal ASIP yang disimpan di cooler } \\
\text { bag dalam suhu 0-40 C } \\
\text { Makanan/ minuman yang boleh diberikan pada bayi } \\
\text { berusia kurang dari 6 bulan }\end{array}$ & Pilihan ganda \\
5 & $\begin{array}{l}\text { Anjuran Kementerian Kesehatan RI terkait } \\
\text { pemberian makanan pada bayi dan anak. }\end{array}$ & Pilihan ganda \\
6 & $\begin{array}{l}\text { PP no. 33 tahun 2012 tentang pemberian ASI } \\
\text { eksklusif }\end{array}$ & Pilihan ganda \\
7 & $\begin{array}{l}\text { Kelompok Pendukung Ibu sebagai salah satu inovasi } \\
\text { untuk meningkatkan cakupan ASI eksklusif }\end{array}$ \\
8 & $\begin{array}{l}\text { Isapan bayi pada putting ibu merangsang produksi } \\
\text { ASI } \\
9\end{array}$ & $\begin{array}{l}\text { ASI merupakan makanan IDEAL untuk bayi yang } \\
\text { aman, bersih, mengandung banyak antibodi yang } \\
\text { dibutuhkan bayi pada awal kehidupannya } \\
\text { Risiko kanker payudara dan ovarium pada Ibu } \\
\text { menyusui lebih tinggi dibandingkan dengan ibu } \\
\text { yang tidak menyusui }\end{array}$ \\
\hline
\end{tabular}

\section{Hasil dan Pembahasan}

Kegiatan webinar ini dilaksanakan secara daring dengan zoom meeting pada hari Selasa, 22 Juni 2021, pada pukul 13.30-15.30 yang dihadiri oleh 150 peserta. Mayoritas peserta yang hadir $(91,3 \%)$ adalah calon ibu/usia dewasa muda, $8,1 \%$ adalah ibu bayi/balita, dan $0,7 \%$ adalah staf Puskesmas. Kegiatan webinar diawali dengan pemutaran video-video terkait ASI eksklusif sebelum dibuka oleh MC, lalu dilanjutkan dengan pre test. Pre test dilakukan dengan media google form dimana peserta diminta untuk menjawab pertanyaan yang sudah dipersiapkan dalam waktu kurang lebih 10 menit. Acara dilanjutkan dengan pemaparan materi dari ketiga narasumber dengan masing-masing alokasi waktu untuk setiap narasumber adalah 20 menit.

Narasumber I yaitu Ibu Sri Wahyuni, S.ST., M.Kes yang merupakan Kepala Seksi Kesehatan Keluarga dan Gizi Dinas Kesehatan Kota (DKK) Surakarta (Gambar 2). Narasumber 1 memberikan materi terkait kebijakan-kebijakan terkait ASI ekslusif dan inovasi dari DKK Surakarta untuk meningkatkan cakupan ASI eksklusif melalui Kelompok Pendamping Ibu (KPI). Narasumber 2 adalah Ibu Setyaningrum Rahmawaty, PhD yang memberikan materi terkait manfaat menyusui ditinjau dari aspek kesehatan dan fisiologis (Gambar 3). Narasumber 3 adalah Ibu Dyah Intan Puspitasari, M.Nutr yang memberikan sharing pengalaman tentang bagaimana tetap dapat menyusui secara eksklusif bagi ibu bekerja beserta kiat-kiat bagaimana memberikan ASI pada ibu bekerja (Gambar 4). Setelah penyampaian materi dari ketiga narasumber, kegiatan dilanjutkan dengan sesi tanya jawab dan diskusi dengan narasumber yang dipandu oleh moderator, Ibu Siti Nurokhmah, M.Sc. 


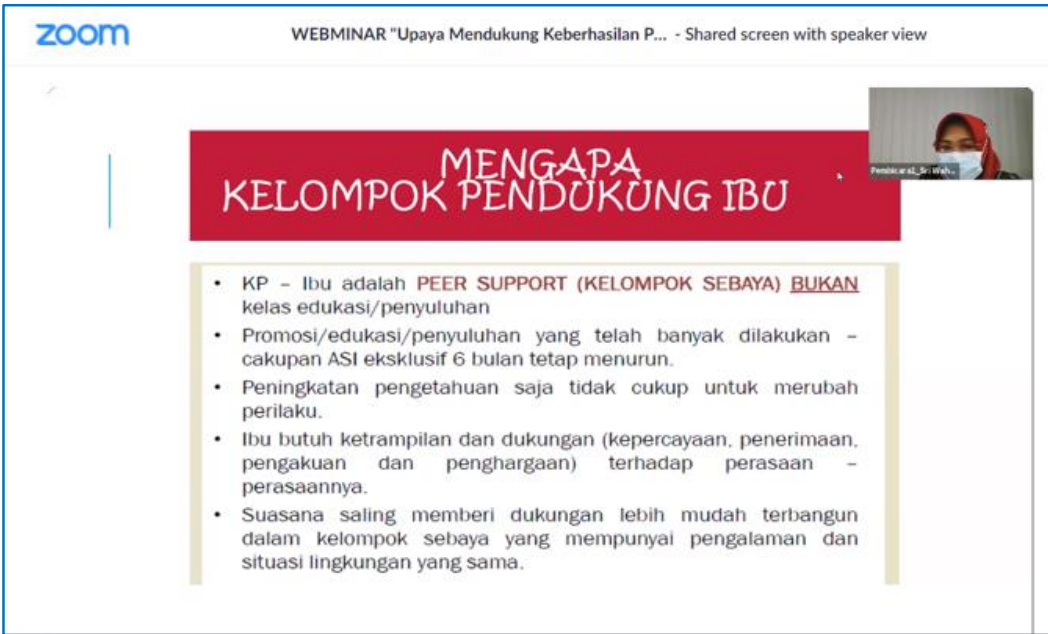

Gambar 2. Screenshoot penyampaian materi oleh narasumber 1

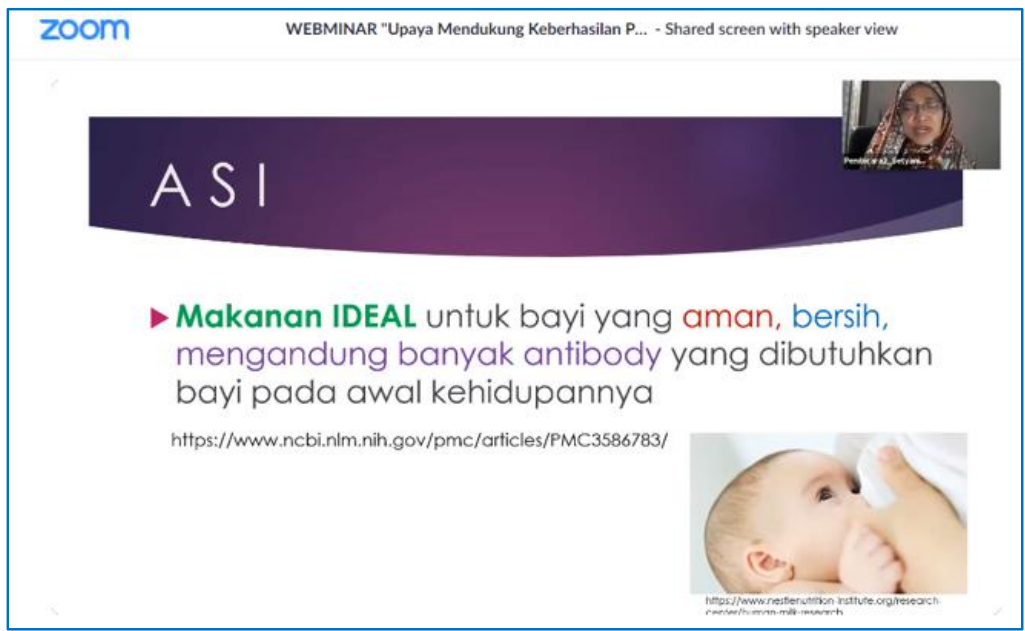

Gambar 3. Screenshoot penyampaian materi oleh narasumber 2

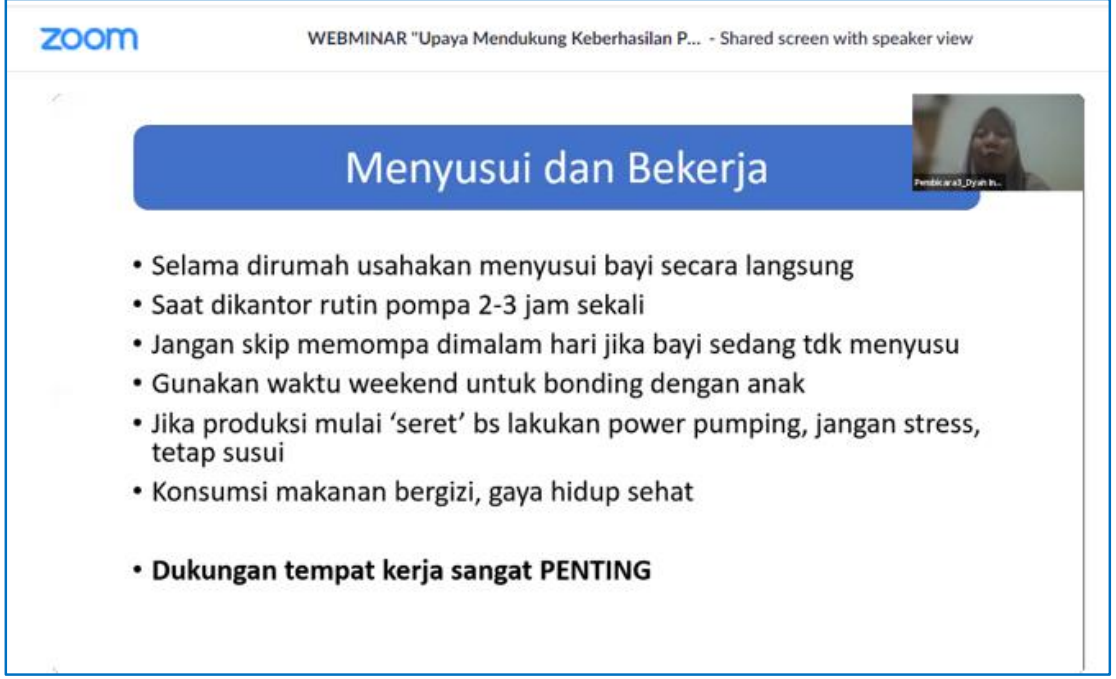

Gambar 4. Screenshoot penyampaian materi oleh narasumber 3 
Materi pertama tentang kebijakan-kebijakan terkait ASI eksklusif diberikan untuk memberi pemahaman kepada audiens bahwa pemberian ASI eksklusif ini merupakan salah satu target nasional. Peran pemerintah dalam menetapkan kebijakan yang mendukung pemberian ASI eksklusif sangat penting untuk keberhasilan program ini. Narasumber juga menyampaikan terkait inovasi program KPI yang diharapkan dapat memberikan inspirasi untuk dikembangkan di berbagai daerah sebagai salah satu program pendukung ASI eksklusif. Materi kedua yang diberikan terkait manfaat ASI ditinjau secara fisiologis dan kesehatan. Pemberian materi-materi tersebut telah terbukti meningkatkan pemahaman dan pengetahuan peserta terkait kebijakan dan manfaat ASI eksklusif secara signifikan $(\mathrm{p}=0,000)$ (Tabel 2). Melalui pemahaman terkait manfaat dari pemberian ASI ini maka diharapkan dapat meningkatkan kesadaran bagi para ibu untuk dapat memberikan ASI kepada bayinya secara eksklusif. Dari narasumber ketiga, dijelaskan mengenai kiat-kiat menyusui pada ibu bekerja. Materi ini diberikan kepada para peserta karena kondisi ibu yang bekerja menjadi salah satu faktor yang dapat menghambat keberhasilan pemberian ASI eksklusif. Kondisi ibu yang harus kembali bekerja sebelum anak berusia 6 bulan dapat menyebabkan ibu tidak memberikan ASI lagi kepada bayinya (Mudaharimbi, 2021). Melalui materi ini, diharapkan dapat memberikan pemahaman bagaimana langkah yang dapat dilakukan agar ibu dapat mempersiapkan diri dan lingkungannya untuk tetap mendukung pemberian ASI eksklusif setelah kembali bekerja.

Pada akhir kegiatan, peserta diminta untuk mengisi post test melalui goggle form. Pertanyaan pada post test sama dengan pertanyaan pada pretest yang bertujuan untuk melihat outcome keberhasilan pelaksanaan Webinar. Peserta diharapkan dapat memahami materi yang diberikan oleh narasumber dan meningkatkan pengetahuan mereka terkait ASI eksklusif yang ditunjukkan dengan meningkatnya skor post test. Dari 150 peserta yang mengikuti Webinar, 120 peserta yang lengkap mengisi pre test dan post test dan hasilnya dianalisis secara statistik. Hasil dari postest menunjukkan bahwa terjadi peningkatan pengetahuan secara signifikan $(\mathrm{p}=0,000)$ pada kelompok sasaran yang ditunjukkan dengan adanya peningkatan rata-rata nilai pre test 7,3 menjadi 8,6 pada post test-nya (Tabel 2). Adanya peningkatan pada nilai pengetahuan ini diharapkan meningkat juga pemahaman sasaran tentang ASI eksklusif sehingga dapat membagikan informasi dan mendukung ibu menyusui dalam memberikan ASI eksklusif kepada anak hingga usia 6 bulan. Jika dilihat per pertanyaan, seperti yang ditampilkan Tabel 3, terlihat bahwa kurang dari $60 \%$ peserta belum memiliki pengetahuan yang bagus terkait penyimpanan ASI perah (ASIP) dan peraturan pemerintah (PP) terkait ASI eksklusif (pertanyaan no. 1,2,3, dan 6). Setelah mengikuti webinar, jumlah peserta yang mampu menjawab dengan benar di 4 pertanyaan tersebut mengalami peningkatan, menjadi lebih dari $70 \%$. Dari analisis per pertanyaan tersebut juga dapat dikatakan bahwa pengetahuan peserta dalam hal pengertian ASI eksklusif (no 4), anjuran pemberian makan pada bayi (no. 5) juga sudah cukup baik sebelum webinar dan meningkat setelah menyimak materi dari narasumber. Pre test dan post test juga mencakup pertanyaan mengenai upaya meningkatkan cakupan ASI eksklusif (no 7) dan manfaat ASI (no 910), serta proses produksi ASI (no. 8). Selain topik pertanyaan, dapat dilihat juga melihat bahwa bentuk soal mungkin mempengaruhi ketepatan jawaban; peserta cenderung menjawab dengan tepat pada soal yang berbentuk pernyataan benar/salah (no. 8-10) dibandingkan dengan soal berbentuk pilihan ganda (no 1-7).

Tabel 2. Hasil pre- dan posttest peserta

\begin{tabular}{ccccc}
\hline Nilai & Mean & Standar Deviasi & N & p-value) \\
\hline Pretest & 7,2 & 1,4 & 120 & 0,000 \\
Postest & 8,8 & 1,2 & 120 & \\
\hline
\end{tabular}


Tabel 3. Hasil pretest dan posttest per pertanyaan

\begin{tabular}{|c|c|c|c|}
\hline \multirow[t]{2}{*}{ No. } & \multirow[t]{2}{*}{ Pertanyaan } & \multicolumn{2}{|c|}{$\begin{array}{l}\text { Peserta yang } \\
\text { menjawab dengan } \\
\text { benar, } \mathrm{n}(\%)\end{array}$} \\
\hline & & Pretest & Posttest \\
\hline 1 & Jarak waktu memompa ASI yang ideal saat di kantor bagi ibu bekerja & $89(59.3)$ & $\begin{array}{c}119 \\
(79.9)\end{array}$ \\
\hline 2 & $\begin{array}{l}\text { Cara penanganan yang dianjurkan pada pompa ASI setelah digunakan } \\
\text { pada } 1 \text { sesi pumping di kantor }\end{array}$ & $83(55.3)$ & $\begin{array}{c}122 \\
(81.9)\end{array}$ \\
\hline 3 & $\begin{array}{l}\text { Daya tahan maksimal ASIP yang disimpan di cooler bag dalam suhu } \\
0-40^{\circ} \mathrm{C}\end{array}$ & $65(43.3)$ & $\begin{array}{c}107 \\
(71.8)\end{array}$ \\
\hline 4 & $\begin{array}{l}\text { Makanan/ minuman yang boleh diberikan pada bayi berusia kurang } \\
\text { dari } 6 \text { bulan }\end{array}$ & $\begin{array}{l}115 \\
(76.7)\end{array}$ & $\begin{array}{l}126 \\
(84.6)\end{array}$ \\
\hline 5 & $\begin{array}{l}\text { Anjuran Kementerian Kesehatan RI terkait pemberian makanan pada } \\
\text { bayi dan anak. }\end{array}$ & $\begin{array}{c}141 \\
(94.0)\end{array}$ & $\begin{array}{l}143 \\
(96.0)\end{array}$ \\
\hline 6 & PP no 33 tahun 2012 tentang pemberian ASI eksklusif & $76(50.7)$ & $\begin{array}{c}108 \\
(72.5)\end{array}$ \\
\hline 7 & $\begin{array}{l}\text { Kelompok Pendukung Ibu sebagai salah satu inovasi untuk } \\
\text { meningkatkan cakupan ASI eksklusif }\end{array}$ & $\begin{array}{c}107 \\
(71.3)\end{array}$ & $\begin{array}{c}131 \\
(87.9)\end{array}$ \\
\hline 8 & Isapan bayi pada putting ibu merangsang produksi ASI & $\begin{array}{c}147 \\
(98.0)\end{array}$ & $\begin{array}{c}149 \\
(100.0)\end{array}$ \\
\hline 9 & $\begin{array}{l}\text { ASI merupakan makanan IDEAL untuk bayi yang aman, bersih, } \\
\text { mengandung banyak antibody yang dibutuhkan bayi pada awal } \\
\text { kehidupannya }\end{array}$ & $\begin{array}{c}150 \\
(100.0)\end{array}$ & $\begin{array}{c}148 \\
(99.3)\end{array}$ \\
\hline 10 & $\begin{array}{l}\text { Risiko kanker payudara dan ovarium pada Ibu menyusui lebih tinggi } \\
\text { dibandingkan dengan ibu yang tidak menyusui }\end{array}$ & $\begin{array}{c}120 \\
(80.0)\end{array}$ & $\begin{array}{c}123 \\
(82.6)\end{array}$ \\
\hline
\end{tabular}

Selain itu, peserta juga diminta untuk memberikan saran terhadap pelaksanaan webinar. Peserta menyampaikan bahwa webinar berlangsung dengan baik dan peserta merasa puas dengan pelaksanaan kegiatan ini. Dalam skala 1 - 4 (tidak puas - sangat puas), 31 peserta memberikan skor 3, sedangkan 118 sisanya memberikan skor 4. Keberlanjutan dari kegiatan ini diharapkan dapat mendorong dilaksanakannya kegiatan-kegiatan serupa berupa Webinar series yang membahas berbagai tema lanjutan yang dapat mendukung praktek-praktek menyusui yang direkomendasikan. Selain itu, dapat juga dilakukan rencana follow-up dengan membentuk komunitas dengan kelompok sasaran sebagai pendamping kepada busui dan calon busui. Kegiatan yang dapat dilakukan antara lain memberikan sharing informasi dan pengalaman dalam mendukung praktek menyusui yang optimal untuk mendukung keberhasilan ASI eksklusif.

\section{Simpulan}

ASI merupakan sumber nutrisi terbaik bagi bayi. Pemberian ASI saja sampai anak berumur 6 bulan memberikan banyak sekali manfaat bagi ibu dan anak. Untuk mencapai target nasional pemenuhan ASI eksklusif, maka pemberian edukasi kepada masyarakat menjadi salah satu cara yang dapat dilakukan. Edukasi dapat menigkatkan pengetahuan kelompok sasaran dan nantinya dapat meningkatkan kesadaran akan pentingnya ASI eksklusif. Kelompok sasaran diharapkan dapat menjadi kader perubahan untuk komunitas yang ada di sekitarnya. Kegiatan ini diharapkan dapat berlanjut dengan kegiatan webinar series dengan tema-tema lain terkait ASI yang mendukung praktek-praktek menyusui yang direkomendasikan. Terbentuknya komunitas yang mendukung ASI eksklusif juga diharapkan menjadi upaya tindak lanjut untuk mendukung keberhasilan ASI eksklusif. 


\section{Persantunan}

Penulis mengucapkan terima kasih kepada Dinas Kesehatan Kota Surakarta atas kolaborasinya pada kegiatan Webinar ini. Dinas Kesehatan Kota Surakarta telah mengirimkan salah satu narasumber yang memberikan materi terkait kebijakan ASI eksklusif pada kegiatan pengabdian ini. Apresiasi juga diberikan kepada Universitas Muhamadiyah Surakarta yang telah memberikan dukungan pendanaan untuk pelaksanaan kegiatan pengabdian masyarakat ini melalui program Hibah Integrasi Terpadu.

\section{Referensi}

Aktaç, S., Sabuncular, G., Kargin, D., \& Gunes, F. E. (2018). Evaluation of Nutrition Knowledge of Pregnant Women before and after Nutrition Education according to Sociodemographic Characteristics. Ecology of Food and Nutrition, 57(6), 441-455. https://doi.org/10.1080/03670244.2018.1544561

Dinas Kesehatan Jawa Tengah. (2019). Profil Kesehatan Provinsi Jawa Tengah Tahun 2019. Diakses dari www.dinkesjatengprov.go.id [26 Juni 2021]

Endeshaw, M., Shiferaw, S., Zelalem, A., Ayenew, M., \& Yirgu, R. (2017). Effect of Nutrition Education on Pregnancy Specific Nutrition Knowledge and Healthy Dietary Practice among Pregnant Women in Addis Ababa. https://doi.org/10.4172/2090-7214.1000265

Kemenkes, National Population and Family Planning Board, Indonesia, S., Kemenkes, M. of H., \& ICF. (2018). Indonesia Demographic and Health Survey 2017. BKKBN, BPS, Kemenkes, and ICF.

Kavle, J. A., LaCroix, E., Dau, H., \& Engmann, C. (2017). Addressing barriers to exclusive breast-feeding in low- and middle-income countries: a systematic review and programmatic implications. Public Health Nutrition, 20(17), 3120-3134. https://doi.org/10.1017/S1368980017002531

Meek, J. Y., Feldman-Winter, L., \& Noble, L. (2020). Optimal Duration of Breastfeeding. In Pediatrics, 146(5), American Academy of Pediatrics. https://doi.org/10.1542/peds.2020021063

Mudaharimbi, EP. (2021). Self-efficacy of primigravida working mothers in the success of breastfeeding. Jurnal Promkes, 9(1). http://dx.doi.org/10.20473/jpk.V9.I1.2021.28-35

Rollins, N. C., Bhandari, N., Hajeebhoy, N., Horton, S., Lutter, C. K., Martines, J. C., Piwoz, E. G., Richter, L. M., \& Victora, C. G. (2016). Why invest, and what it will take to improve breastfeeding practices? The Lancet, 387(10017), 491-504. https://doi.org/10.1016/S0140-6736(15)01044-2

Toquero, C. M., \& Talidong, K. J. (2020). Webinar Technology: Developing Teacher Training Programs for Emergency Remote Teaching amid COVID-19. Training Programs Interdiscip J Virtual Learn Med Sci, 11(3), 200-203. https://doi.org/10.30476/ijvlms.2020.86889.1044

Victora, C. G., Bahl, R., Barros, A. J. D., França, G. V. A., Horton, S., Krasevec, J., Murch, S., Sankar, M. J., Walker, N., Rollins, N. C., Allen, K., Dharmage, S., Lodge, C., Peres, K. G., Bhandari, N., Chowdhury, R., Sinha, B., Taneja, S., Giugliani, E., ... Richter, L. (2016). Breastfeeding in the 21st century: Epidemiology, mechanisms, and lifelong effect. The Lancet, 387(10017), 475-490. https://doi.org/10.1016/S01406736(15)01024-7

WHO. Breastfeeding. Diakses dari https://www.who.int/health-topics/breastfeeding\#tab=tab_3 [12 Juni 2021] 